\title{
Population and distribution of Sunda porcupine (Hystrix javanica F. Cuvier, 1823) in designated area of Cisokan Hydropower, West Java, Indonesia
}

\author{
IRINA A. MUSTIKASARI ${ }^{1,2}$, SUSANTI WITHANINGSIH ${ }^{1,2,3, \bullet}$, ERRI N. MEGANTARA ${ }^{1,2,3}$, \\ TEGUH HUSODO ${ }^{1,2,3}$, PARIKESIT ${ }^{1,2,3}$ \\ ${ }^{1}$ Department of Biology, Faculty of Mathematics and Natural Sciences, Universitas Padjadjaran. Jl. Raya Bandung-Sumedang Km. 21 Jatinangor, \\ Sumedang 45363, West Java, Indonesia. Tel. +62-22-7796412 ext. 104, Fax. +62-22-7795545. `email: susanti.withaningsih@ unpad.ac.id \\ ${ }^{2}$ Center for Environment \& Sustainability Science, Universitas Padjadjaran. J1. Sekeloa Selatan I, Bandung 40132, West Java, Indonesia \\ ${ }^{3}$ Graduate School of Sustainability Science, Universitas Padjadjaran. Jl. Dipati Ukur No. 35, Bandung 40132, West Java, Indonesia
}

Manuscript received: 20 December 2018. Revision accepted: 24 February 2019.

\begin{abstract}
Mustikasari IA, Withaningsih S, Megantara EN, Husodo T, Parikesit. 2019. Population and distribution of Sunda porcupine (Hystrix javanica F. Cuvier, 1823) at designated area of Cisokan Hydropower, West Java, Indonesia. Biodiversitas 20: 762-769. One of the endemic species of Indonesia is the Sunda porcupine (Hystrix javanica). Sunda porcupine is a big rodent which has unique defense mechanism behavior using its quills. This research was conducted in the designated area of Cisokan Hydropower (PLTA Cisokan), in West Java, Indonesia. The method in this study is qualitative to determine the total population and distribution. Data collection techniques were carried out by sign surveys (burrow, footprints, quills, food sites, and feces), camera traps, and semistructured interviews. The result shows the number of porcupine populations in the designated area of Cisokan Hydropower is 6-29 individuals. Porcupine population is distributed in five regions, namely the first region consisting of Pasir Gagak, Cigintung, Batu Sahulu and Batu Nunggul; the second region is Batu Tumpeng and Batu Wulung; the third region is Curug Japarana; the fourth region consists of Sarongge and Cadas Gantung; and the fifth region is Pongpok. Based on the type of land cover, the porcupine population is commonly found in the types of shrub/huma /ladang, talun, and natural forests.
\end{abstract}

Keywords: Designated area of Cisokan Hydropower, distribution, Hystrix javanica, population

\section{INTRODUCTION}

Indonesia is known to be rich in native Indonesian fauna and to be the second country with the highest endemic species (Whitten et al. 2004; Mittermeier et al. 2005). One of the endemic species of Indonesia is the Sunda porcupine (Hystrix javanica) which can be found in Java, Bali, Sumbawa, Flores, Lombok, Madura, and Tonahdjampea (Van Weers 1979, 1983). Sunda porcupine is one of the unique mammals whose half part of the body is covered with quills used as self-defense. Sunda porcupine's body is covered by a thousand quills with variations in size, shape, and color. The quills can be differentiated into 4 types: quills, true quills, transitional quills, and rattle quills (Barthelmess 2006). Sunda porcupine has blackish to dark brown body color. Long quills are commonly white with black lines and short quills are generally black to dark brown (Payne et al. 1985).

Porcupine is protected by Environmental and Forestry Minister Regulation No P.20 of 2018. Based on the IUCN red list, Sunda porcupine belongs to the category of Least Concern or is not particularly concerned about its status. Despite their protected status, the hunt and trade of these animals continue to occur. Local people consider it as traditional medicine that can eliminate various diseases such as asthma and its meat is nutritious and is considered healthier than beef. In recent year, the utilization of porcupine increases. Besides porcupine quills are used for decorative and aesthetic elements (Inayah 2016).

Considering to high value of porcupine, market demand of porcupine definitely increases. In South Africa, the highest part of porcupine body trade is on quill. They exported porcupine quill overseas (Chevallier and Ashton 2006). In Malaysia, porcupine meat was popular as an alternative meat product in the domestic market. Half of Malaysian Urban Consumers acknowledged that porcupine meat can be eaten (halal) and has high nutritional values (Norsuhana et al. 2012). In Singapore, bezoars of porcupine are the most popular and it can be one of the main causes of overhunting (Chung et al. 2016). As market demand on porcupine meat and its savor increases, hunting, and trade of them will continue to increase too.

The high level of hunting and trade of these animals can be the largest factor of population decline (Miller-Gulland and Bennett 2003; Borschberg 2006). In addition, habitat loss, fragmentation, and land use modification also can contribute to decrease in porcupine numbers (Corlett 1992; Brook et al. 2003). Some efforts need to be done are to increase the porcupine livestock for fulfilling the demand of porcupine trade market (Inayah 2016). Considering the high value of porcupine, not only to increase the porcupine livestock, but the efforts to keep their increasing numbers in wildlife and improve the captive breeding are also necessary to be done. The reason is that the meat from 
wildlife porcupine is cheaper than that from livestock porcupine (Brook et al. 2010).

Research about Sunda porcupine (Hystrix javanica) is still small in number. As endemic species of Java, its existence will continue to decrease with increasing human density in Java. The high density of human resulted in the deforestation of forest which is the natural habitat of Sunda porcupine. Now, only 1.1 million hectares of forest remain on Java (Prasetyo et al. 2009). One of the known locations of Sunda porcupine habitat is designated area of Cisokan Hydropower (PLTA Cisokan) which is located in border area between West Bandung and Cianjur districts, West Java Province, Indonesia. This location provides various types of ecosystems, such as natural forests, riparians, shrubs, production forests, taluns, gardens and huma or paddy fields. Therefore, research on the population of Sunda porcupine species in the designated area of Cisokan Hydropower is needed and it is expected that this place can be considered as the conservation location of Sunda porcupine.

\section{MATERIALS AND METHODS}

This research was conducted in the designated area of Cisokan Hydropower, West Java, Indonesia in February to April 2017. The method in this study is qualitative to determine the total population and distribution. Data collection techniques were carried out by sign surveys with explorations (burrow, footprints, quills, food sites, and feces), camera traps, and semi-structured interviews. Data collection of sign surveys includes footprints, quills, feeding sites, and burrows. The signs were measured, captured, and tagged using GPS. The burrow was identified based on signs such as footprints, quills, and feeding sites. This shows that the burrow is still used by porcupines.

Camera traps are installed at some point that is considered potential. The camera traps are 17 units and installed in 20 different locations. Camera trap installation is performed alternately to represent all locations. Total install time at each location is different with the shortest time span of 11 days and the longest time span of 35 days. Semi-structured interviews were conducted to collect data on the characteristics, presence, distribution, and disturbance of porcupine.

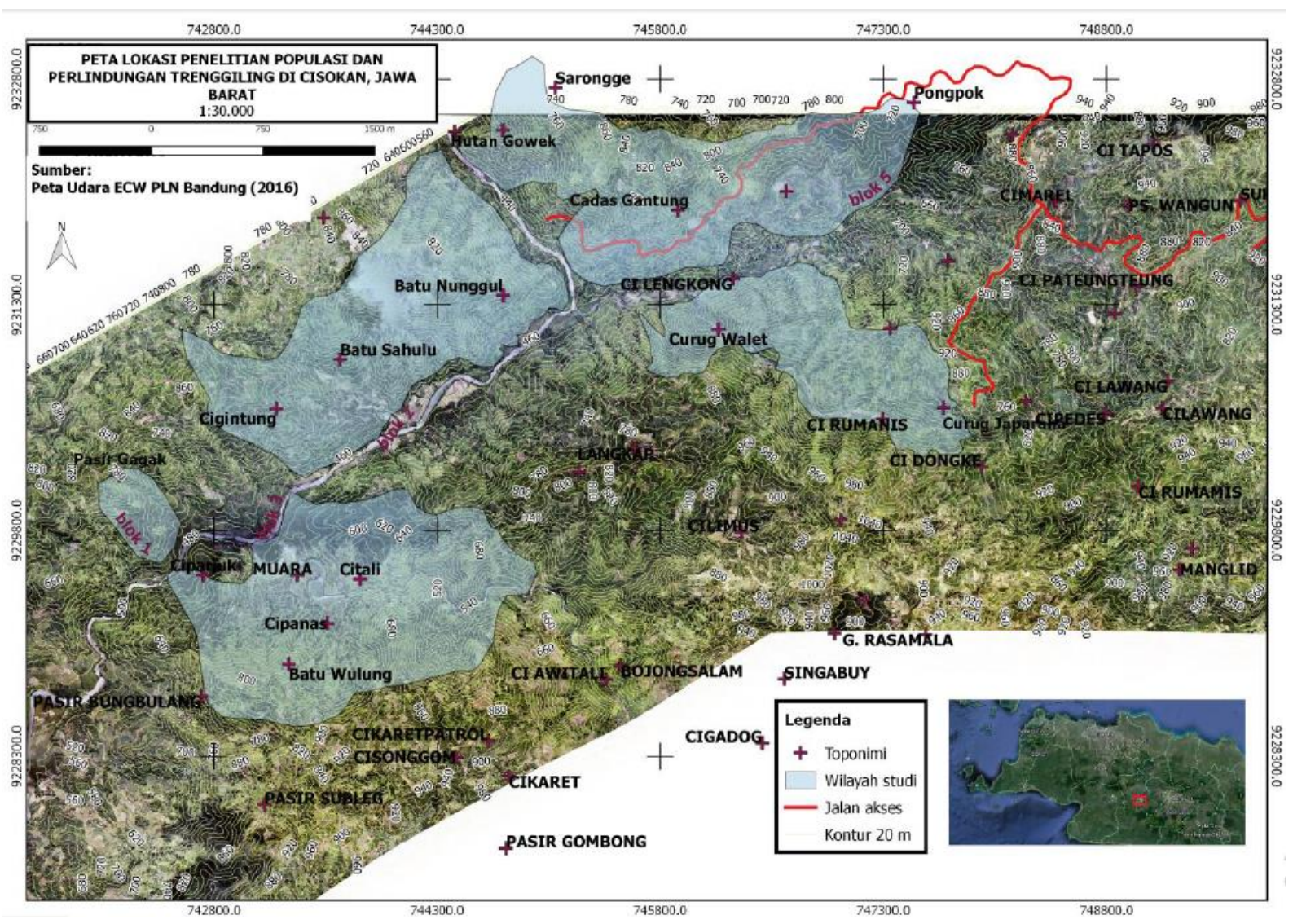

Figure 1. Map of research locations in the designated area of Cisokan Hydropower, West Java, Indonesia 
Estimated number of individuals is based on the results of camera trap recording and signs such as active burrow, scratches, quills and the measurements of footprints which are quite clearly visible. Estimation of the number of individuals is done with the assumption that the sign and camera trap recording results are still within the range area of a porcupine, it means that the sign are considered from the same individual, as it is known that porcupines have a range of 5-30 ha (PLN 2014). Camera trap data results are identified based on meeting time, morphology, location and direction of movement. Determination of the number of individual porcupines through the sign in the form of an active burrow is carried out assuming that the active burrow can be inhabited by 1-4 individual porcupines. Porcupine of the Hystricidae family generally live solitary, so the porcupine will be with one another during the breeding and breeding season, and the number of children per child is about 1-3 (Van Aarde 1985; Olsen and Lewis 1999). So in one burrow, it might be filled by four porcupines.

The distribution data is presented in the form of a map, where the coordinate points of the sign and camera trap obtained are interpreted in map form with the division of the region as shown in Figure 1. Distribution maps are created using the QGIS software. Then the data are analyzed descriptively.

\section{RESULTS AND DISCUSSION}

The result of the sign survey was 34 signs consisting of burrows, footprints, feces, quills, scratches, and feeding sites (Table 1). The sign mostly found is burrow. Burrow is the easiest sign to find because other signs are easily washed away by rain or covered by soil, while the burrow can last long enough and its appearance is bigger.

The porcupine burrow found at the study site consisted of two types, namely ground holes and rock slits. As with the new world of porcupine, they use various types of burrows, such as caves, large rock slits, hollow logs, and trees (Roze 1987). Porcupines generally dig their own burrows; they use fore-claws to dig the earth to make the burrows more secure and comfortable. The burrow is up to $20 \mathrm{~m}$ deep. The entrance hole of the burrow is generally more than one, can be 2-4 holes, are equipped with tunnel and each ending has enlarged chamber (Greaves and Khan 1978). The burrows found in the designated area of Cisokan Hydropower are 18. Four of them have many holes in various sizes from $16 \mathrm{~cm} \times 16 \mathrm{~cm}$ to $100 \mathrm{~cm} \times 65 \mathrm{~cm}$ (Figure 2), but the depth is only $3 \mathrm{~m}$.

Porcupine burrows which are still active to use are eight burrows. Active burrows can be marked by the presence of footprints, feces, scratches, or quills around the burrow. This active burrow was used for estimating the population. Ground burrows type was found mostly active. These were built by some rock on the top of the hole. Generally, in this study area, the burrows were fully covered by roots and shrubs. So, the light of sun couldn't shine on them directly, so, some locations are at wet condition. The soil around the burrow was solid and clear too.

Signs found in less than five are footprints, feces, quills and scratch. These four types of sign can be easily lost due to buried by dirt, swept by water, or hidden deep in the burrow. Porcupine footprints are between $40 \mathrm{~mm}$ x $40 \mathrm{~mm}$ to $50 \mathrm{~mm} \times 50 \mathrm{~mm}$. This difference in size can be caused by different soil textures. Some footprints are found on solid soil while the others are found on wet soil (Figure 3). Porcupine's feces are found in burrows, close to entrance/exit holes. These feces are black with rotten leaflike texture torn apart.

Table 1. Signs of Porcupine found at the study site

\begin{tabular}{ll}
\hline Sign & Number of sign \\
\hline Burrow & 18 \\
Footprint & 5 \\
Feces & 1 \\
Quills & 2 \\
Scratch & 1 \\
Feeding site & 7 \\
Total & 34 \\
\hline
\end{tabular}

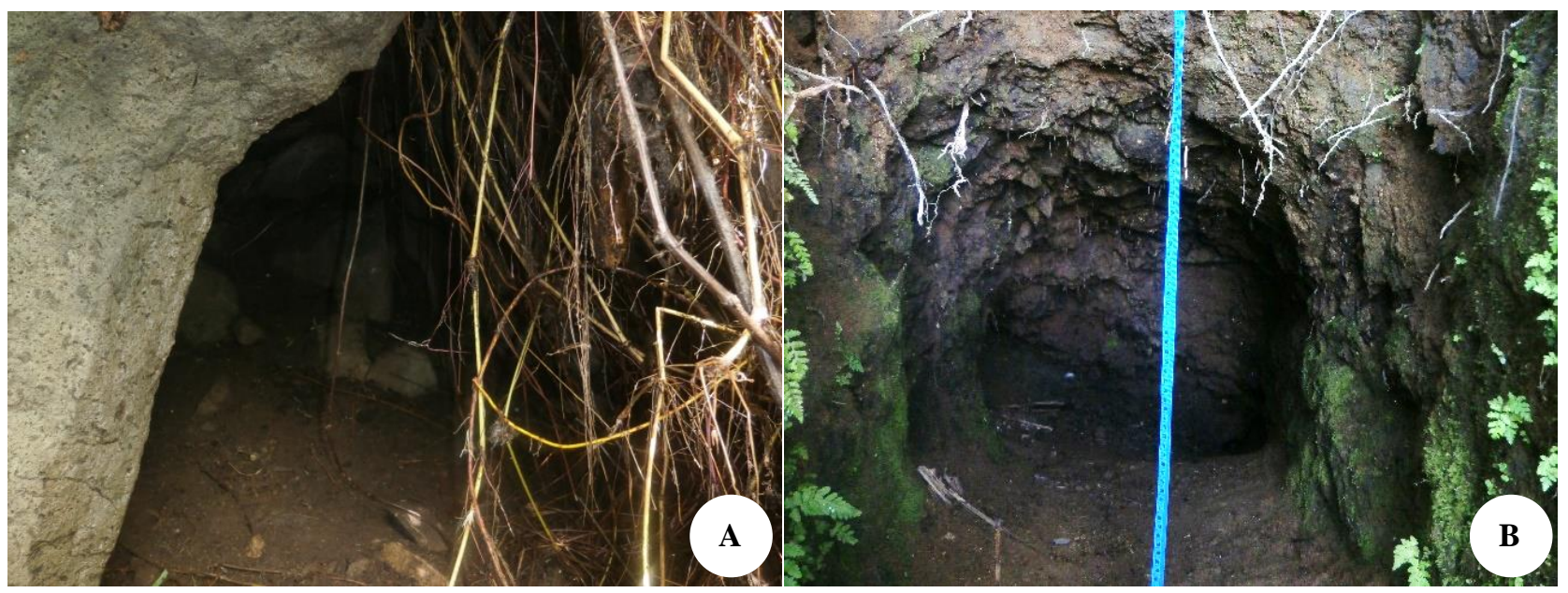

Figure 2. Porcupine burrow in (A) Pasir Gagak and (B) Batu Wulung of Cisokan Hydropower, West Java, Indonesia 


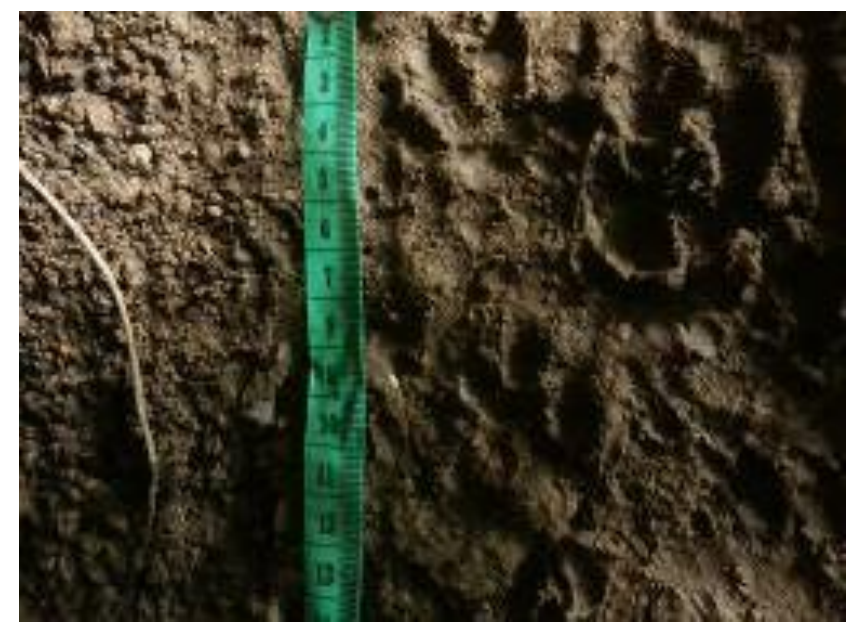

Figure 3. Porcupine footprints at Sarongge of Cisokan Hydropower, West Java, Indonesia

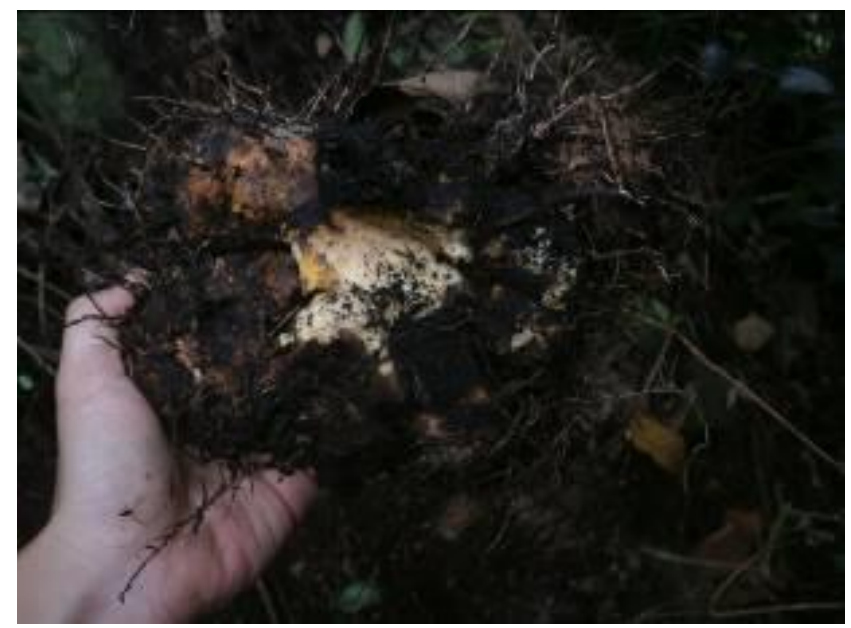

Figure 4. Dioscorea hirsuta eaten by porcupines in Pasir Gagak of Cisokan Hydropower, West Java, Indonesia

Feeding sites that were found are buds and tubers (Dioscorea hirsuta) (Figure 4). Farida (2015) explained the types of porcupine feeding site such as tubers (Dioscorea hirsuta), bamboo shoots, fruit, and pteridophyte buds. Feeding sites are found in almost every burrow location. Feeding site found on Batu Nunggul probably was only as a foraging location. In Batu Nunggul, there is no burrow to be found, the closest burrow from this place is in Cigintung. Cigintung was a place between Pasir Gagak and Batu Nunggul in which mostly porcupine was found.

Camera trap (CT) installation was carried out in 20 different locations. Four camera traps were installed in four different locations to get pictures of porcupine. There were 15 pictures captured by camera trap from the four camera traps installed. Porcupine activity recorded by camera trap is in the time span of 20.56-05.15 WIB (Table 2). This span shows the activity of nocturnal animals, and generally, porcupines are known as nocturnal animals (Payne et al. 1985).
Table 2. Time and activity of porcupine recorded by camera trap in Cisokan Hydropower, West Java, Indonesia

\begin{tabular}{lcccl}
\hline Location & Date & $\begin{array}{c}\text { Time } \\
\text { (WIB) }\end{array}$ & $\begin{array}{c}\text { No. of } \\
\text { Individu }\end{array}$ & Activities \\
\hline Cigintung & $10 / 02 / 2017$ & 03.40 & 1 & Walking \\
Cigintung & $10 / 02 / 2017$ & 03.44 & 1 & Walking to \\
Cigintung & $22 / 02 / 2017$ & 23.07 & 1 & Walking \\
Sarongge & $22 / 02 / 2017$ & $04: 19$ & 1 & Walking \\
Sarongge & $22 / 02 / 2017$ & $04: 58$ & 1 & Walking \\
Sarongge & $26 / 02 / 2017$ & $04: 16$ & 1 & Walking \\
Pasir Gagak & $04 / 03 / 2017$ & 20.56 & 3 & Walking \\
Pasir Gagak & $04 / 03 / 2017$ & 20.59 & 1 & Walking \\
Pasir Gagak & $04 / 03 / 2017$ & $23: 17$ & 1 & Walking \\
Pasir Gagak & $04 / 03 / 2017$ & 23.19 & 1 & Walking \\
Pasir Gagak & $05 / 03 / 2017$ & 00.58 & 1 & Walking \\
Pasir Gagak & $05 / 03 / 2017$ & 04.25 & 1 & Walking \\
Pasir Gagak & $06 / 03 / 2017$ & 05.15 & 1 & Walking \\
Pasir Gagak & $07 / 03 / 2017$ & 04.20 & 1 & Walking \\
Curug Japarana & $16 / 03 / 2017$ & 21.01 & 1 & Walking \\
\hline
\end{tabular}

Estimation of porcupine populations is based on result of sign survey and camera trap. The total data obtained is 34 data of sign and 15 data of camera traps. Based on the results of the identification, the estimated number of individual porcupine in the designated area of Cisokan Hydropower was 6-28 individuals (Table 3). This review is based on the identification of the location of sign, individual morphology, direction of movement, and time of discovery. The study area reached more than 723 ha, if one individual porcupine can have a home range of 5-30 ha (PLN 2014), at least there will 24 individual that exists in the designated area of Cisokan Hydropower.

Porcupines found in Pasir Gagak, Cigintung, and Batu Nunggul are thought to be the same individuals because the three regions are considered to be within the same porcupine's home range area. It is estimated that there are 3-12 individuals in Pasir Gagak area. The minimum number of 3 individuals was obtained from camera trap results which showed three porcupines in one picture (Figure 5). The maximum number of camera trap in Pasir Gagak comes from the possibility of different individuals from the four images that captured. The type of data found at the location of Pasir Gagak is quite complete. The number of active burrows was three. In this case, the three burrows are used in the calculation of the number of individuals. This is based on the nature of male porcupine which can have overlapping home-range with five different females (Olsen and Lewis 1999). Home range overlap between members of the same pair is $75 \%$ on average (Mori et al. 2014). So, the sign gives estimation that the burrows have maximum of 12 porcupines. The results of this identification indicated that porcupine can live in groups in an area/burrow. 
Table 3. Estimated number of porcupine Individuals in Cisokan Hydropower, West Java, Indonesia

\begin{tabular}{lccccccccc}
\hline \multirow{2}{*}{ Location } & \multicolumn{8}{c}{ Type of data } & $\begin{array}{c}\text { No. of } \\
\text { individual }\end{array}$ \\
\cline { 2 - 7 } & CT & Fc & FP & Q & FS & Sc & Br & $1-12$ \\
Pasir Gagak & $3-5$ & 1 & 1 & 1 & 1 & - & $1-12$ & $3-12$ \\
Cigintung & $1-2$ & - & $1-2$ & - & - & - & $1-4$ & \\
Batu Nunggul & - & - & - & - & 1 & - & - & \\
Batu Tumpeng & - & - & - & - & - & - & $1-4$ & $1-4$ \\
Curug Japarana & 1 & - & - & - & 1 & - & $1-4$ & $1-4$ \\
Sarongge & $1-2$ & - & $1-2$ & - & 1 & 1 & $1-4$ & $1-4$ \\
Cadas Gantung & - & - & - & - & $1-2$ & - & - & \\
Pongpok & - & - & - & 1 & - & - & $1-4$ & $1-4$ \\
Total & & & & & & & & $6-28$ \\
Note:
\end{tabular}

Note: $\mathrm{CT}=$ Camera Trap; $\mathrm{Fc}=$ Feces $; \mathrm{FP}=$ Foot Print; $\mathrm{Q}=$ Quills; FS $=$ Feeding Site; $\mathrm{Sc}=$ Scratch $; \mathrm{Br}=$ Active Burrow

At Cigintung site, two footprints and one active burrow were found. From camera trap data, there are three pictures at different times with different body sizes, so there is a possibility that these pictures show different individuals. Camera trap results are estimated to have 1-3 individuals. However, there was also an active burrow which revealed a maximum estimate at the Cigintung site, namely 4 individuals.

In Batu Nunggul, only porcupine feeds were found. This location is possibly a feeding site by porcupines. The location of Batu Nunggul is close enough to Cigintung location, about $2-3 \mathrm{~km}$ in a straight measurement. This distance can be reached by a porcupine in one roach. Porcupines can explore for as much as $15 \mathrm{~km}$ (Schütze 2002).

The result from Sarongge area, near Cadas Gantung area, indicated that the porcupine in this area could be the same individual. At Sarongge area, porcupine was caught by camera trap and left a sign. Camera trap results capture three pictures of porcupines at different times, the second and third picture is considered as repetition of first picture because at this location, it is done twice, so it is estimated that only 1-2 individuals are in this location. Aside from camera trap, footprints, feeding sites, scratches and an active burrow were also found. Active burrows estimate 14 individuals. So, at the Sarongge location, it is estimated that only 1-4 individuals. At Cadas Gantung, feeding site is found with an estimated number of individuals 1-2. This location is assumed to be used for foraging.

The next location is Batu Tumpeng, which is quite far from the locations of previous sign findings. Besides, this location is separated from the Cisokan River and Langkop settlement, which increases the possibility of this location being isolated geographically. At this location, an active burrow was found which was indicated by the presence of quills in front of the burrow. It can be estimated that the number of individuals is between 1-4 individuals.

Other locations that also quite far from the location of the previous signs are the location of Curug Japarana. Curug Japarana is separated by Cirumamis, Cilengkong River, Cisokan River, and Langkop settlement. So, the individuals found in this location are estimated to be different from the individuals found in the previous location. camera trap results showed just one porcupine. But another sign is found namely several burrows, and one of them is active burrow marked by the presence of feeding site. So, in this location, it can be estimated that there was 1-4 individual. Pongpok, which is the location of the porcupine findings, is quite far from other locations. There is an active burrow marked by the presence of quills in front of the entrance hole. 1-4 individuals are estimated in this location.

Based on the results of the sign and camera trap, the map shows porcupines are distributed in five regions. The first region is Pasir Gagak, which is found in Block 1 and Cigintung, Batu Sahulu and Batu Nunggul which are located in Block 2, the second region are Batu Tumpeng and Batu Wulung in Block 3, the third region is Curug Japarana in block 4, the fourth region is Sarongge and Cadas Gantung in block 5, and the fifth region is Pongpok in block 5 (Figure 6). The grouping of these five regions is based on the $15 \mathrm{~km}$ porcupine cruising capability (Schütze 2002), and with home range area is 5-30 ha (PLN 2014). Besides, another consideration of regions grouping is based on geographic isolation, i.e., the presence of large river flow separating the first and the second, third, and fourth regions. In addition, there is a fairly large settlement location separating the second and third regions.

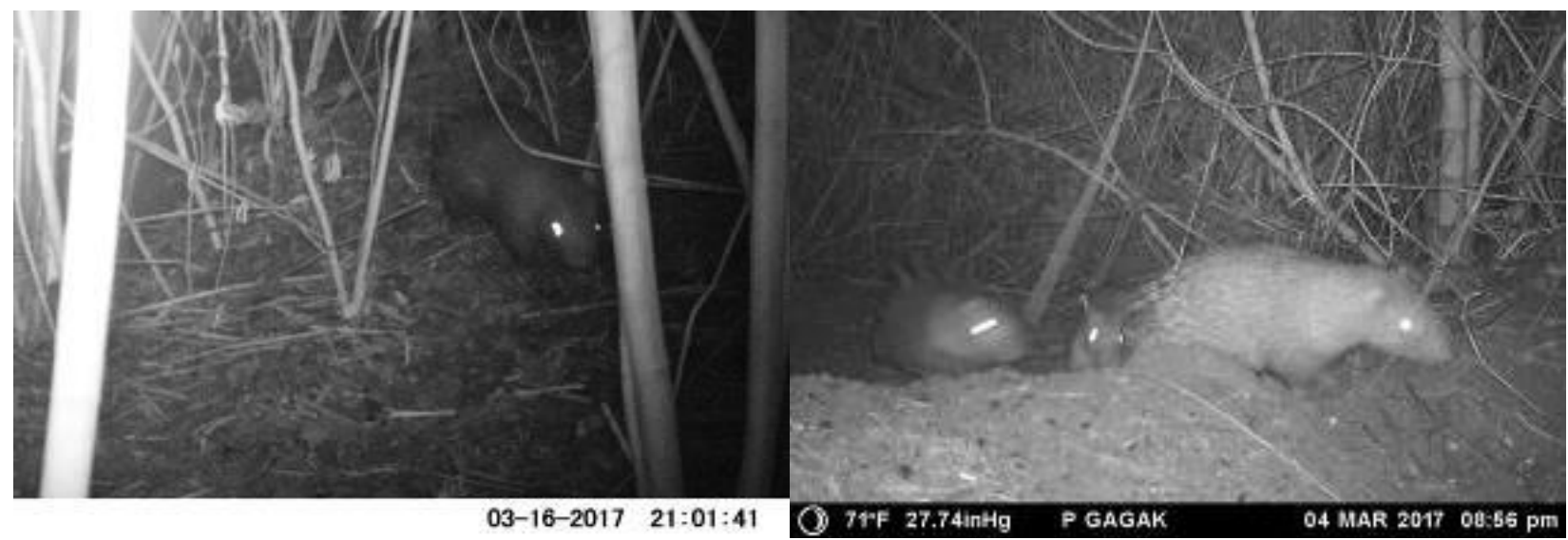

Figure 5. Porcupine caught by camera trap at Pasir Gagak of Cisokan Hydropower, West Java, Indonesia 


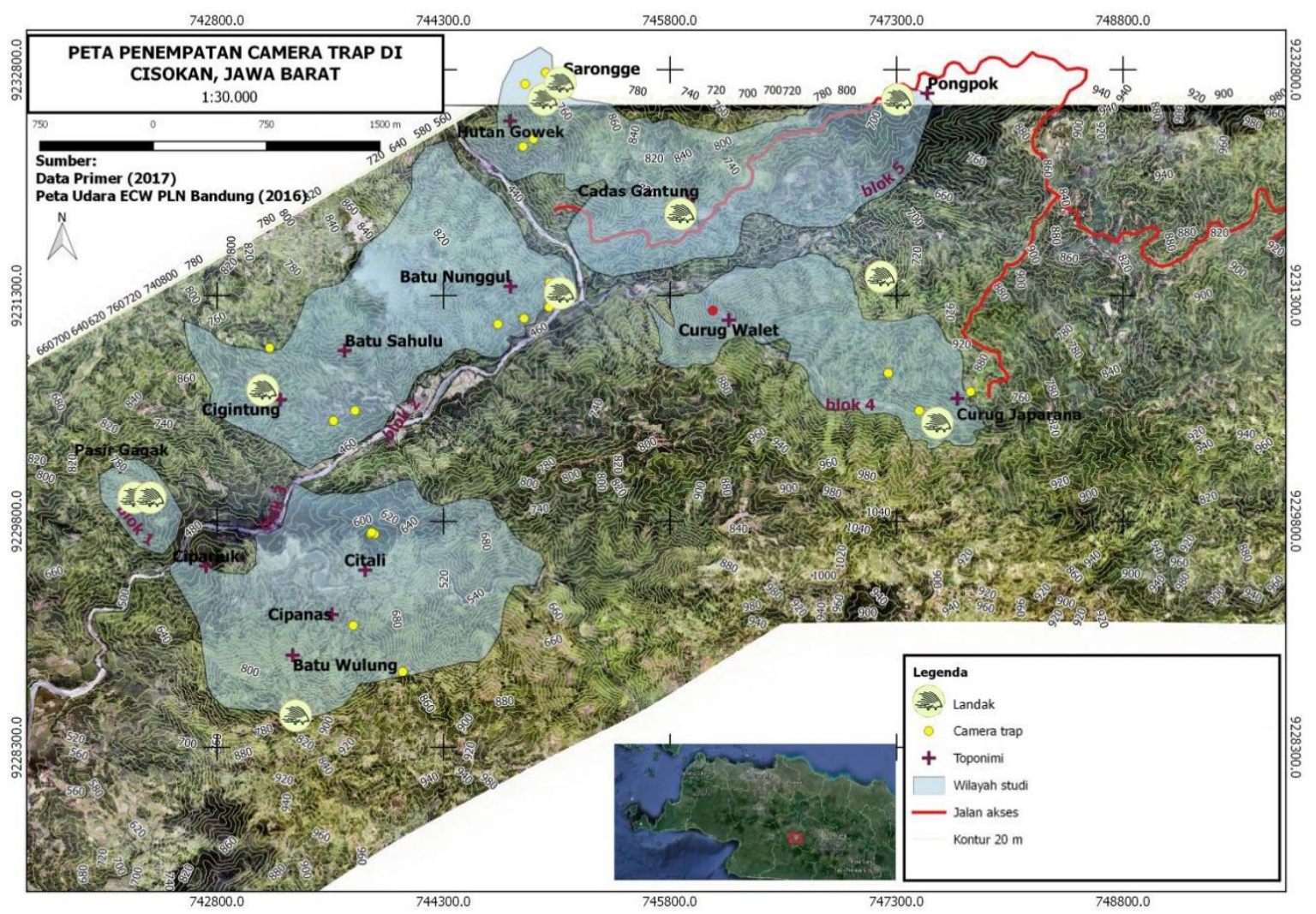

Figure 6. Distribution map of porcupine in the designated area of Cisokan Hydropower, West Java, Indonesia

Almost all the river in this study area was large, heavy stream, and deep. Based on the function of hydropower, heavy stream is used to get the energy. In this case, a large river can be a geographic isolation factor. Settlement is also another factor of geographic isolation, because human presence can increase the possibility of porcupine hunting.

Based on the type of land covering, porcupine is more commonly found in shrub/huma/field, talun, and natural forests. Woods (1973) explained that good forest habitats for porcupines are under herbs, grasses, and shrubs. Zeiner et. al. (1990) added that porcupine foraging habitat (genus Erethizon) was meadows, bushy, and riparian. The location with shrub/humaltalun land cover type is Pasir Gagak, Batu Nunggul, Pongpok, and half part of the Curug Japarana location. This type of shrub/huma/talun has similar plant composition, namely kaso (Saccharum spontaneum), kirinyuh (Chromolaena odorata), kaliandra (Calliandra calothyrsus), and kiseureuh (Piper aduncum). Porcupine in eastern Brazil also prefers secondary forest and avoids structurally simplified and highly disturbed vegetation types, early secondary forest, and open areas (Giné et al. 2015)

Locations with natural forest land cover types are only found in half part of the Curug Japarana location. Natural forest in the location of Curug Japarana has less varied vegetation composition such as kiara karet (Ficus sp.), kiara beas (Ficus sp.), sampora (Microcos hirsute), and hampelas (Ficus ampelas). Locations with talun land cover types are found in the locations of Cigintung and Sarongge.
Some areas in Cigintung has a vegetation composition of teak (Tectona grandis) and mahogany (Swietenia sp.) domination, while the Sarongge area is a mixed talun with a vegetation composition consisting of bananas, ferns, Araceae, calliandra. Some other areas of Cigintung are not so different from the Sarongge area.

In this study area, porcupine has the same use of burrow with pangolin. Therefore, there's a possibility of space use competition. Almost all type of porcupine burrow can be occupied by pangolin. They can dig their own burrow using their fore-claws as deep as they can do. But if there is another species living in it, porcupine will move from that burrow, to find or to build another burrow. The same space use competition between porcupine and pangolin was proved by pictures from camera trap (Figure 7). Although in different time, Porcupine and pangolin were found in the same place, namely in Pasir Gagak and Cigintung. Pangolin itself was only captured once on a camera trap, it may mean nothing, because porcupine in Pasir Gagak lived in a group, or it could be just a track of foraging way.

There is lack of competition in this species, because porcupine can live together, in same area, but in different burrow. There is some overlap between total home range of pair of porcupine, although intensive area is used largely, the area may be defended as a territory (Corbet 1991). In Pasir Gagak, porcupine was found in a group. There were three individuals that were captured by camera trap, although they were commonly found solitary. This proves the lack of competition in one species. 


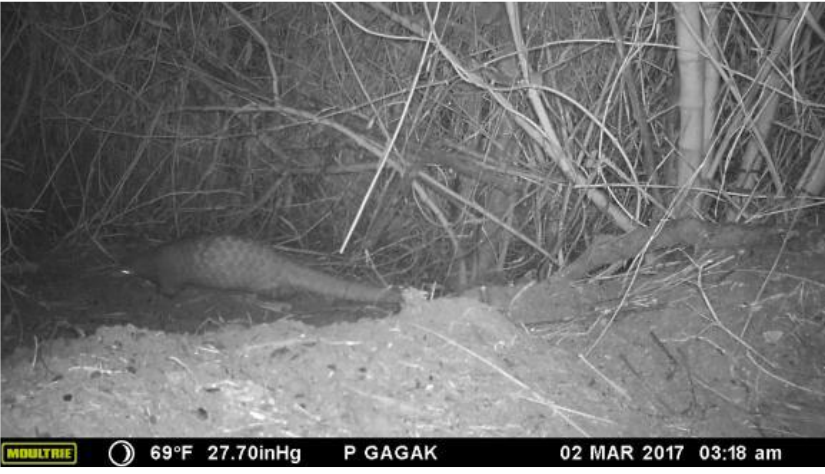

Figure 7. Pangolin in Pasir Gagak of Cisokan Hydropower, West Java, Indonesia

Predator of porcupine in this study area is Javan leopard (Panthera pardus). Local people said that porcupine can be eaten by leopard. In the emergency situation, porcupine will make a sound from the quills, and then throw the quills to predator. In some burrows, the quills are found; it indicates the effort of self-defense around the burrow place against predators' attack.

In general, the potential threat to porcupines existence is the condition of several study sites that have experienced landslides. The lack of stands can cause continuous avalanches. If this continues to occur, the location of the burrow which is generally sloping slopes has the potential to be covered with landslides and can minimize the foraging area and natural habitat for porcupine. This condition will urge porcupine to come to human area. When it happens, porcupine will be considered as a pest. This condition actually happens in some locations. Porcupine attacks the farm by taking the crop and makes it damage. The most attacked crops by porcupine are chili and tuber. And local people try to hunt porcupine as if they expel a pest. Some of them kill it and make it as a meal. The hunting activity conducted by local people at the beginning was intended to catch porcupine for its meat to be consumed by themselves.

In this study area, porcupine hunting was not a big problem for porcupine existence. Porcupine hunting was still only a few, although it still happens. Most of porcupine hunters come from the outside village. They used a dog as a hunter, and they follow it till they got the porcupine. Another way to hunt porcupine is by trapping porcupine with rope net or blowing smoke into the entrance/exit area of burrow and waiting for it to come out from another entrance/exit hole and it can be caught easily. Local people use porcupine quills for esthetic and some believe that porcupine quills can evade an attack of black magic. They use the quill as a hairpin for a pregnant woman. Some people eat porcupine meat which is tasty and easy to cook. Although they use porcupine for their own need, if it happens continuously, the hunt for porcupine will increase too. Someday it will be a big problem for the existence of porcupine. High demand of porcupine in international trading will urge the hunter to hunt the porcupine in nature or to develop captive breeding. The high level of hunting and trade of these animals can be the largest factor of population decline (Miller-Gulland and Bennett 2003; Borschberg 2006).

Building the road and facilities will increase habitat loss, fragmentation and land used modification in designated area. Landslides that happened are caused by activity of building road and facilities. This species has poor self-defense on habitat damage. Even though this species seem to be adaptable (Payne et al. 1985), but if there is no preventive action to do, it won't survive in this area. The preventive way that can be done is making hole tunnel as manipulative burrow, or build ecological corridors, such as the Eco-Link which may help to restore the fragmented landscape by connecting the patches in forest (Chung et al. 2014).

In conclusion, based on the results of the sign survey and camera trap, the number of porcupine populations in the designated area of Cisokan Hydropower is 6-29 individuals. This porcupine population is distributed in five regions, namely the first region consisting of Pasir Gagak, Cigintung, and Batu Nunggul; the second region including Batu Tumpeng; the third region consisting of Curug Japarana; the fourth region consisting of Sarongge and Cadas Gantung; and the fifth region including Pongpok. If based on the type of land cover, the porcupine population is commonly found in the types of shrub/huma /ladang, talun, and natural forests. Predator of porcupine that found in this study area is Javan leopard. The competitor of space use by porcupine is pangolin. Generally, the potential threat to porcupine existence is the condition of several study sites that have experienced landslides. In some cases, the continuous hunt for porcupines can increase the possibility of population number decrease.

\section{ACKNOWLEDGEMENTS}

This study was supported by Perusahaan Listrik Negara (PLN) of Indonesia government. We are grateful for surveyor/ field team for conducting the survey in a field.

\section{REFERENCES}

Barthelmess LE. 2006. Hystrix africaeaustralis. Mammalian Species 788: 1-7.

Borschberg P. 2006. The trade, forgery and medicinal use of porcupine bezoars in the early Modern Period (c.1500-1750). Oriente 14: 60-78.

Brook BW, Sodhi NS, Ng PKL. 2003. Catastrophic extinctions follow deforestation in Singapore. Nature 424: 420-423.

Brooks EGE, Roberton SI, Bell DJ. 2010. The conservation impact of commercial wildlife farming of porcupines in Vietnam. Biol Conserv 143: $2808-2814$

Chevallier N, Ashton B. 2006. A Report on the Porcupine Quill Trade in South Africa. International Fund for Animal Welfare (IFAW), Yarmouth, USA.

Chung YF, Kolandavelu RR, Ngiam RWJ, Shunari M, Neves ES, Tan MK, Tan AHN, Chin HK, Gan JWM, Chan SKL. 2014. Connecting rainforest nature reserves in Singapore: the first overhead wildlife bridge in tropical Asia. Abstracts of the Biodiversity Research Symposium. Singapore Botanic Gardens, Singapore.

Chung YF, Lim NTL, Shunari M, Wang DJ, Chan SKL. 2016. Records of the Malayan porcupine, Hystrix brachyura (Mammalia: Rodentia: Hystricidae) in Singapore. Nature in Singapore 9: 63-68 
Corlett RT. 1992. The ecological transformation of Singapore, 1819-1990. J Biogeography 19 (4): 411-420

Corbet NU. 1991. Space use and group living in the Cape porcupine (Hystrix africaeaustralis Peters, 1852). [Thesis]. University of Pretoria, Pretoria

Giné GAF, De Barros EH, Duarte JMB, Faria D. 2015. Home range and multiscale habitat selection of threatened thin-spined porcupine in the Brazilian Atlantic Forest. J Mammal 96 (5): 1095-1105

Greaves JH, Khan AA. 1978. The status and control of porcupine, genus Hystrix as forest pest. Commonw For Rev 5: 261-268

Inayah N. 2016. Potensi pengembangan landak (Hystrix sp) sebagai produk komersial. Fauna Indonesia 15: 37-43. [Indonesian]

IUCN. 2018. Hystrix javanica. 2018 IUCN Red List of Threatened Species. http: //www.iucnredlist.org.

Milner-Gulland EJ, Bennet EL. 2003. Wild meat: the bigger picture. Trends Ecol Evol 18: 351-357.

Mittermeier RA, Gil PR, Hoffman M, Pilgrim J, Brooks T, Mittermeier CG, Lamoreux J, da Fonseca GAB. 2005. Hotspots Revisited. Earth's Biologically Richest and Most Endangered Terrestrial Ecoregions. The University of Chicago Press, Chicago, USA.

Mori E, Lovari S, Sforzi A, Romeo G, Pisani C, Massolo A, Fattorini L. 2014. Patterns of spatial overlap in a monogamous large rodent, the crested porcupine. Behavior Proces 107: 112-118.

Norsuhana AH, Shukor MN, Aminah A. 2012. Perceptions on captive malayan porcupine (Hystrix brachyura) Meat by Malaysian urban consumers. Health Environ J 3 (1): 67-78.
Olsen R, Lewis AM. 1999. Porcupine Ecology and Damage Management Techniques for Rural Homeowners. University of Wyoming, Laramie, WY.

Payne J, Francis CM, Phillipps K. 2000. A Field Guide to the Mammals of Borneo. 3rd ed. The Sabah Society, Kota Kinabalu, Malaysia.

PLN. 2014. Laporan Biodiversity Management Plant Upper Cisokan Pumped Storage, PLN, Jakarta. [Indonesian]

Prasetyo LB, Kartodihardjo H, Adiwibowo S, Okarda B, Setiawan Y. 2009. Spatial Model Approach on Deforestation of Java Island, Indonesia. J Integr Field Sci 6: 37-44.

Roze U. 1987. Denning and winter range of the porcupine. Can J Zool 65 (4): 981-986.

Schütze H. 2002. Field Guide to The Mammals of The Kruger National Park. Struik Publishers (Pty) Ltd, Cape Town.

Van Aarde RJ. 1985. Reproduction in captive female cape pocupines (Hystrix africaeaustralis). J Reprod Fert 75: 577-582.

Van Weers D J. 1979. Notes on southeast Asian porcupines (Hystricidae, Rodentia) IV. On the taxonomy of the subgenus Acanthion F. Cuvier. Beaufortia 29 (356): 215-272.

Van Weers D J. 1983. Specific distinction in Old World porcupines. Zoologische Garten 53: 226-232.

Whitten T, Dijk P P van, Curran L, Meijaard E, Supriatna J, Ellis S. 2004. Sundaland. In: Mittermeier R A, Gil P R, Hoffmann M, Pilgrim J, Brooks T, Mittermeier C G, Lamoreux J, da Fonseca G A B. (eds.). Hotspots Revisited: Another look at Earth's richest and Most Endangered Terrestrial Ecoregions. Cemex, Mexico.

Woods C.A. 1973. Erethizon dorsatum. Mamm Species 29: 1-6. 